University of Nebraska - Lincoln

DigitalCommons@University of Nebraska - Lincoln

Nebraska Game and Parks Commission -- Staff

Research Publications

Nebraska Game and Parks Commission

January 1971

\title{
A Study of Primary Productivity in a Nebraska Interstate 80 Lake
}

Gilbert Adrian

Carl Throckmorton

Bob McDonald

Follow this and additional works at: https://digitalcommons.unl.edu/nebgamestaff

Part of the Environmental Sciences Commons

Adrian, Gilbert; Throckmorton, Carl; and McDonald, Bob, "A Study of Primary Productivity in a Nebraska Interstate 80 Lake" (1971). Nebraska Game and Parks Commission -- Staff Research Publications. 27. https://digitalcommons.unl.edu/nebgamestaff/27

This Article is brought to you for free and open access by the Nebraska Game and Parks Commission at DigitalCommons@University of Nebraska - Lincoln. It has been accepted for inclusion in Nebraska Game and Parks Commission -- Staff Research Publications by an authorized administrator of DigitalCommons@University of Nebraska - Lincoln. 


\section{A Study of Primary Productivity in a Nebraska Interstate 80 Lake}

GILBERT ADRIAN, CARL THROCKMORTON and BOB MCDONALD

Transactions of the Kansas Academy of Science, Vol. 73, No. 2, 1970 This issue was published January 15, 1971 


\title{
A Study of Primary Productivity in a Nebraska Interstate 80 Lake
}

\section{GILBERT ADRIAN, CARL THROCKMORTON and BOB MCDONALD ${ }^{1}$}

\begin{abstract}
The primary productivity of a small gravel pit lake in the Platte River Valley of Nebraska was studied for a 2-year period. Daily production rates were estimated from near weekly samples, with calculations done by computer. Emphasis was placed on production under ice during winter conditions. Annual production was estimated and is compared with scveral other lakes in North America.
\end{abstract}

\section{Introduction}

In recent years, the measurement of aquatic productivity has been approached on the basis of the primary productivity concept using the in situ radioactive carbon-14 method. The method was first described by Steeman-Neilsen (1952) as used in measuring organic production in the sea. It has since been used in a variety of freshwater aquatic habitats for masuring primary productivity.

In this study the primary productivity of a small (exposed water table) gravel pit lake, located along Nebraska Interstate 80, was investigated. The carbon-14 method as evaluated by Saunders, et al., (1962) was used.

Gibbon Lake Number 4 (the study lake) is the fourth in a series of five small gravel pits located in the Northeast quadrant of the Gibbon Interchange along Interstate Highway 80 in Buffalo County. Gibbon number 4 is a eutrophic lake of 1.4 acres ( 0.56 hectare) with a maximum depth of slightly less than 10 meters and an average depth of about 6 meters. The sides slope abruptly to a generally flat bottom. The bottom deposits are a mixture of sand and silt. Rooted aquatic plants are rare because of the steep shoreline gradient.

\section{Methods and Techniques}

Measurements of primary productivity were carried out at near weekly intervals from October, 1967 through April 1969, including periods of ice cover during the two winters. Measurements were made at four depths.

Transactions of the Kansas Academy of Science, Vol. 73, No. 2, 1970. Published January 15, 1971.

1 Staff Member Biology Department, Hastings College; Staff Member Physics Department, Hastings College; and Limnologist, Nebraska Game and Parks Commission, Office of Limnology, Hastings College, Hastings, Nebraska respectively. 
The amount of light falling on the surface of the lake was measured to determine how much light energy fell within a four-hour sampling period. This was done by driving an electrometer (Keithley Mod. $610 \mathrm{~A})^{2}$ with a photovoltaic cell (Selenium cell S5M) ${ }^{2}$. The Electrometer read out to a strip-chart recorder. A typical curve of relative light intensity vs. time is shown in Figure 1. Planemetric measurements of winter and spring curves indicate that about 45 percent of the light falling on the lake in one day falls in the four-hour period, 10:00 AM-2:00 PM. When Wetzel (1967) discusses the techniques used in measuring primary production; he suggests breaking the day into five periods for light measurements. Thus, if the day rate curves are symmetrical 25 percent of the day rate will be measured in period II and 30 percent in period III. The curves, as represented in Figure 1, compare favorably with this. Wetzel (1964) made the assumption that productivity is directly proportional to light and points out that this assumption is not always exact. In this paper the same assumption was made and it was further assumed that 45 percent of the day's light fell in the normal four-hour sampling period.

The sampling data, counting data, water chemistry, and correction factors were programmed on an IBM 1130 computer. A correction was made for self-absorption since the mass on the filters was sufficiently large to warrant a correction. In addition the isotropic correction factor was applied. The table in Saunders, et al., (1962) used to calculate the total available carbon in the lake, was read into the computer in order to include this information in the formula for calculating net productivity. The computer was programmed to read data cards with the following

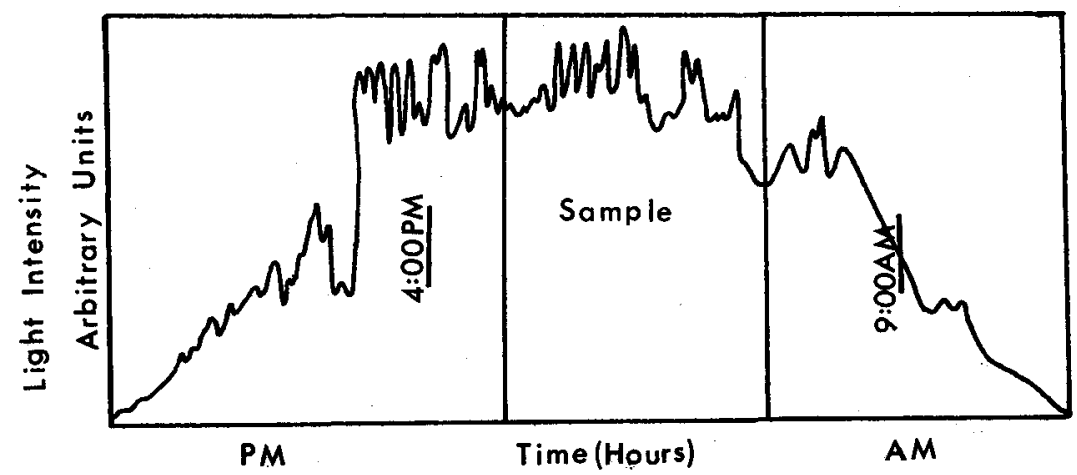

Figure 1. Typical curve of relative light intensity versus time, Gibbon Lake Number 4, 1969.

\footnotetext{
2 does not imply endorsement of product described
} 
information: light bottle ( $\mathrm{cpm})$, dark bottle $(\mathrm{cpm}), \mathrm{pH}$, alkalinity, and sample mass. From this information the computer calculated the net productivity in mg (carbon) per cubic meter per hour. The results could then be further reduced to day-rate productivity and estimates made of the productivity of the lake during the course of one year.

\section{Results}

The Winter Period. The winters were quite different in their severity. The winter of 1967-68 was relatively mild with ice cover on the lake never exceeding a thickness of 12 inches, whereas the winter of 1968-69 was relatively severe with ice cover of nearly 24 inches thickness for extended periods.

The productivity of the lake water as measured $15-25 \mathrm{~cm}$. under the ice during the two winters is shown in Figures 2 and 3. These figures show a significant level of production in the region just under the ice. The lake became temporarily ice-free in early February, 1968 (Figure 2); with a rapid rise in production immediately apparent. A gradual decline in production occurred when the lake again became frozen. This is contrasted with the same period in 1969 (Figure 3) when the lake was covered with about 20 inches of ice and the production was low but measurable.

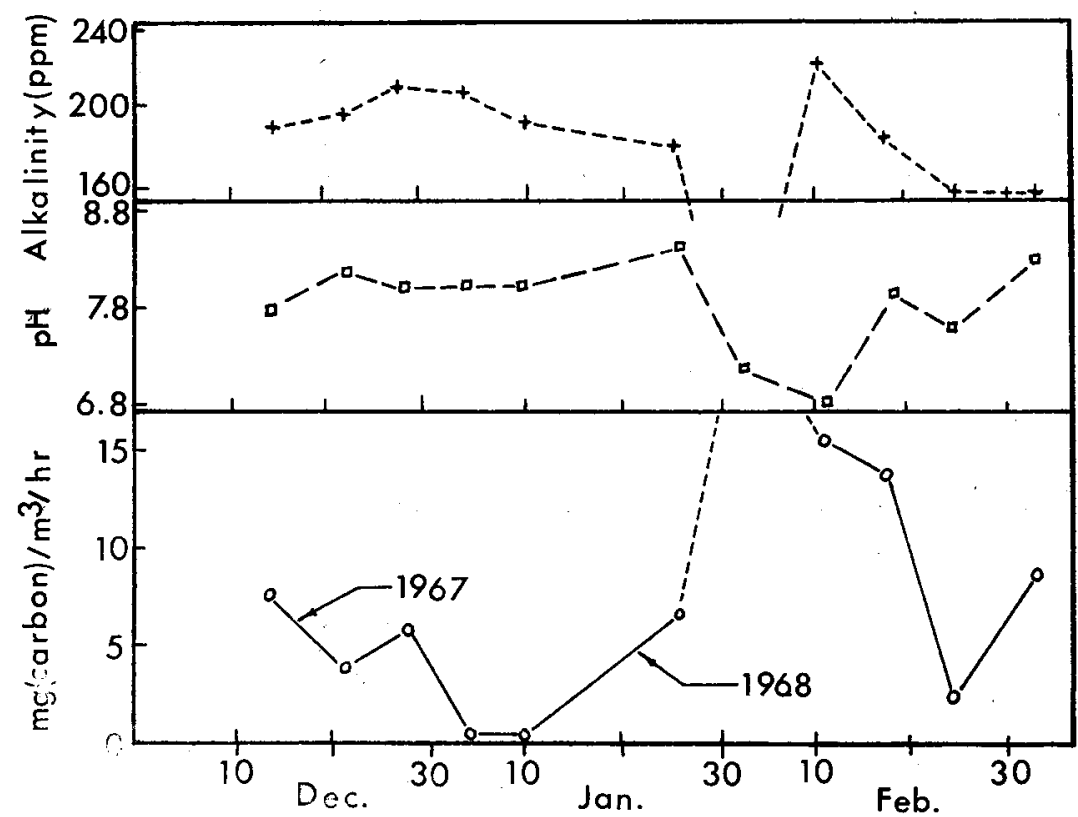

Figure 2. $\mathrm{pH}$, alkalinity, and productivity at surface of water, under ice, Gibbon Lake Number $4,1967-68$. 
The mean relative levels of production observed at the different depths, during these winter months for sixteen weekly measurements were computed and the standard deviation calculated (Table 1 ). The mean data from Table 1 were plotted in yield the net productivity per square meter of lake surface (Figure 4). Integrating down the water column yields a value of 32 milligrams per square meter per hour. This was converted to day-rate by multiplying by 4 (the length of the sampling period in hours) and dividing by 0.45 (from the assumption that the production follows the daily light curve). Thus it was estimated that under one square meter of ice the net productivity per day was approximately 280 milligrams. In view of the large deviation from the mean

Table 1. Mean and standard diviation of sixteen winter productivity samples (mg/m²/hr) Gibbon Lake Number 4, 1967-68, 1968-69.

\begin{tabular}{lcc}
\hline \multicolumn{1}{c}{ Depth } & Mean productivity & Standard deviation \\
\hline Surface & 4.4 & 3.7 \\
$13 / 4$ meters & 4.1 & 4.3 \\
5 meters & 5.0 & 4.8 \\
7 meters & 4.8 & 8.5 \\
\hline \hline
\end{tabular}

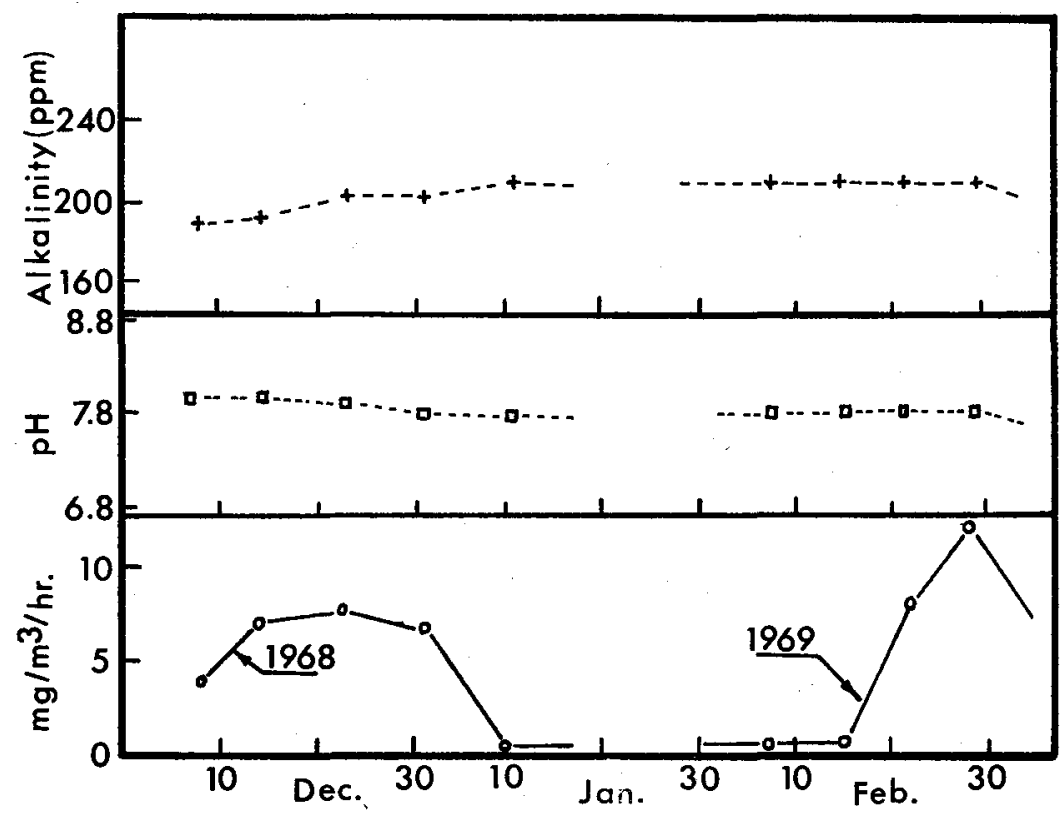

Figure 3. $\mathrm{pH}$, alkalinity and productivity at surface of water, under ice, Gibbon Lake Number 4, 1968-69. 
values found in the winter data this must be viewed as approximate although it does show that significant photosynthetic production took place during the winter period.

During the winter months of 1968-69 the alkalinity varied from a low of 180 to a high of $220 \mathrm{ppm}$., the $\mathrm{pH}$ varied from 7.6 to 8.1. These values appear to be representative of small exposed water table lakes in the sandy areas of the Platte River Valley.

Spring and Summer Data. The spring and summer were characterized by gradual changes in production rates. The highest production occurred in late summer; when the surface temperature had risen to about 25 degrees $C$. but the subsurface water remained somewhat cooler. Little or no correlation was observed between alkalinity, $\mathrm{pH}$, and productivity

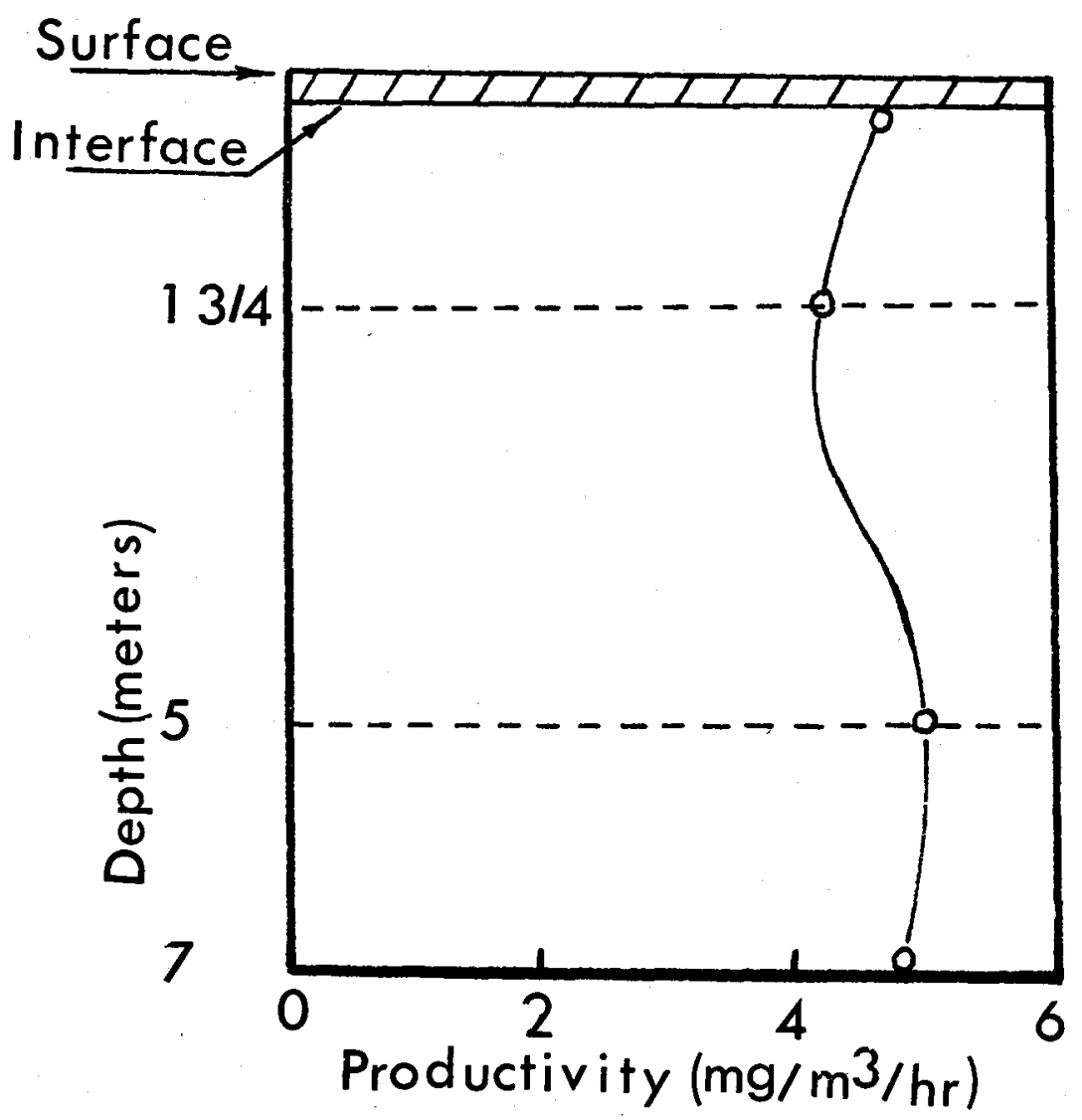

Figure 4. Mean productivity data from two winters showing the net productivity per square meter of lake surface, Gibbon Lake Number 4. 
The mean relative levels of production observed at the different depths, during these winter months for sixteen weekly measurements were computed and the standard deviation calculated (Table 1). The mean data from Table 1 were plotted in yield the net productivity per square meter of lake surface (Figure 4). Integrating down the water column yields a value of 32 milligrams per square meter per hour. This was converted to day-rate by multiplying by 4 (the length of the sampling period in hours) and dividing by 0.45 (from the assumption that the production follows the daily light curve). Thus it was estimated that under one square meter of ice the net productivity per day was approximately 280 milligrams. In view of the large deviation from the mean

Table 1. Mean and standard diviation of sixteen winter productivity samples (mg/m $/ \mathrm{m}^{3} / \mathrm{hr}$ ) Gibbon Lake Number 4, 1967-68, 1968-69.

\begin{tabular}{lcc}
\hline \hline \multicolumn{1}{c}{ Depth } & Mean productivity & Standard deviation \\
\hline Surface & 4.4 & 3.7 \\
$13 / 4$ meters & 4.1 & 4.3 \\
5 meters & 5.0 & 4.8 \\
7 meters & 4.8 & 8.5 \\
\hline \hline
\end{tabular}

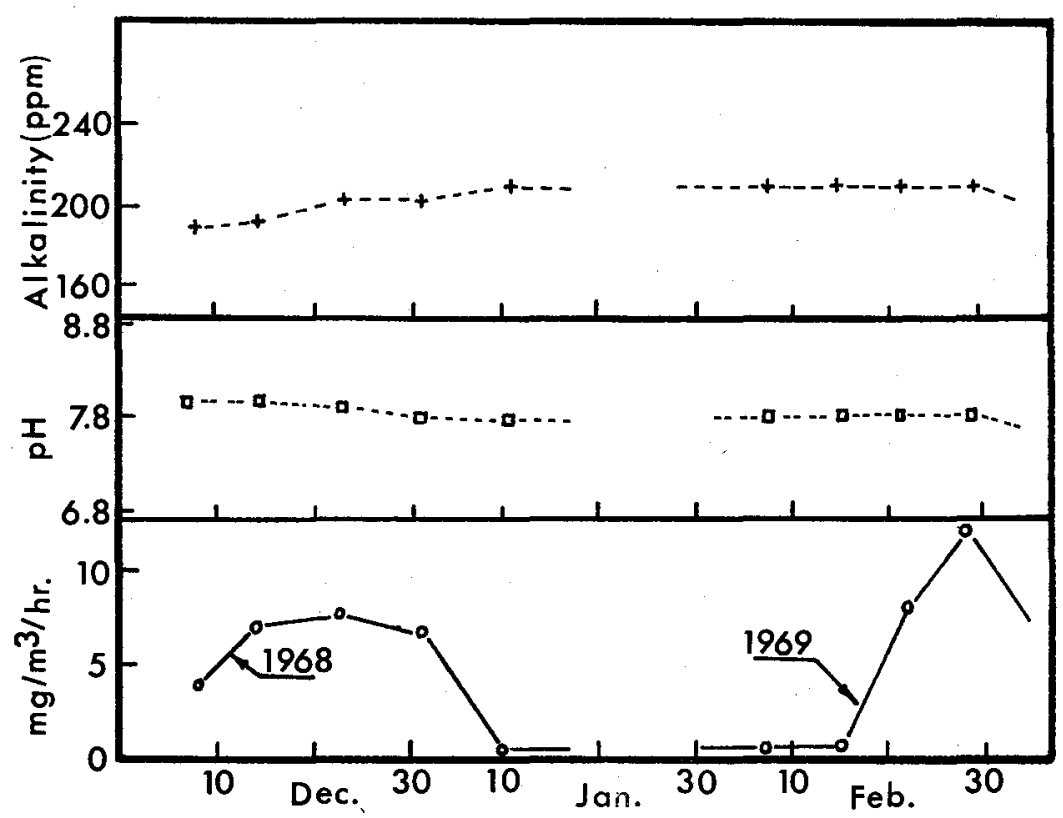

Figure 3. $\mathrm{pH}$, alkalinity and productivity at surface of water, under ice, Gibbon Lake Number 4, 1968-69. 
values found in the winter data this must be viewed as approximate although it does show that significant photosynthetic production took place during the winter period.

During the winter months of 1968-69 the alkalinity varied from a low of 180 to a high of $220 \mathrm{ppm}$., the $\mathrm{pH}$ varied from 7.6 to 8.1. These values appear to be representative of small exposed water table lakes in the sandy areas of the Platte River Valley.

Spring and Summer Data. The spring and summer were characterized by gradual changes in production rates. The highest production occurred in late summer; when the surface temperature had risen to about 25 degrees $\mathrm{C}$. but the subsurface water remained somewhat cooler. Little or no correlation was observed between alkalinity, $\mathrm{pH}$, and productivity

\section{Surface}

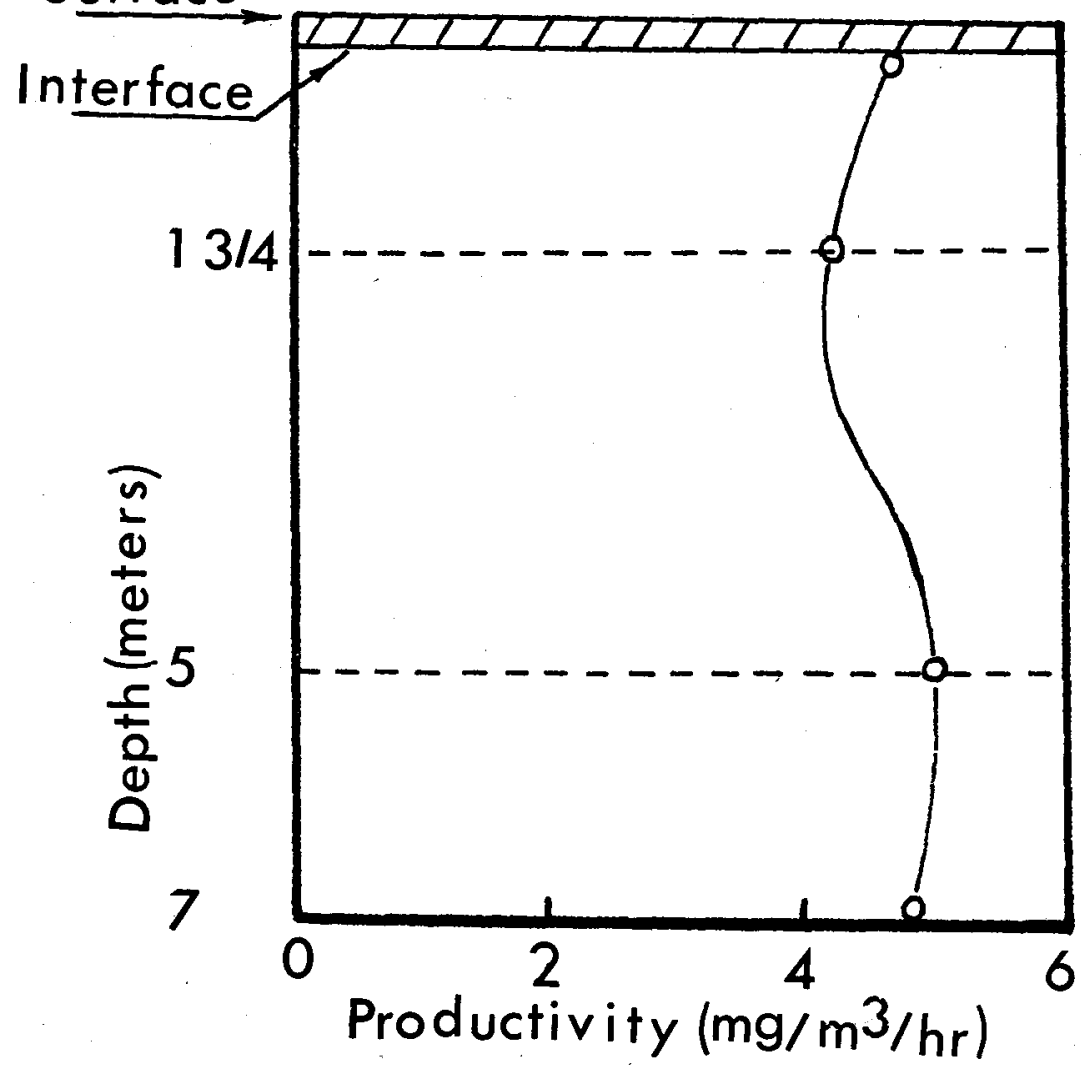

Figure 4. Mean productivity data from two winters showing the net productivity per square meter of lake surface, Gibbon Lake Number 4. 
during this period. Representative data at the $13 / 4$ meter level is plotted in Figure 5. It can be seen that there appears to be little correlation between the rate of variation of productivity, $\mathrm{pH}$, and alkalinity. Water temperature at the 13/4 meter level fell within the 20-25 degree $C$. range.

Late in the summer several algae blooms occurred which resulted in rapid rise in productivity. This increase constituted a significant part of the total production during the year.

Fall Data. The fall of both 1967 and 1968 were sampled and those data converted to estimated day-rates for all four sampling depths. The day-rates for the months of October and November of the two years are plotted in Figure 6. These curves demonstrate how productivity curves may vary from one year to the next.

Annual Rate Estimates. In order to estimate the net productivity of the lake in the course of one year (1968), the day rates were calculated for each day that a sample was taken. These day rates were plotted in Figure 7 and the area under each curve measured in order to obtain the amount of carbon fixed per cubic meter at each sampling depth.

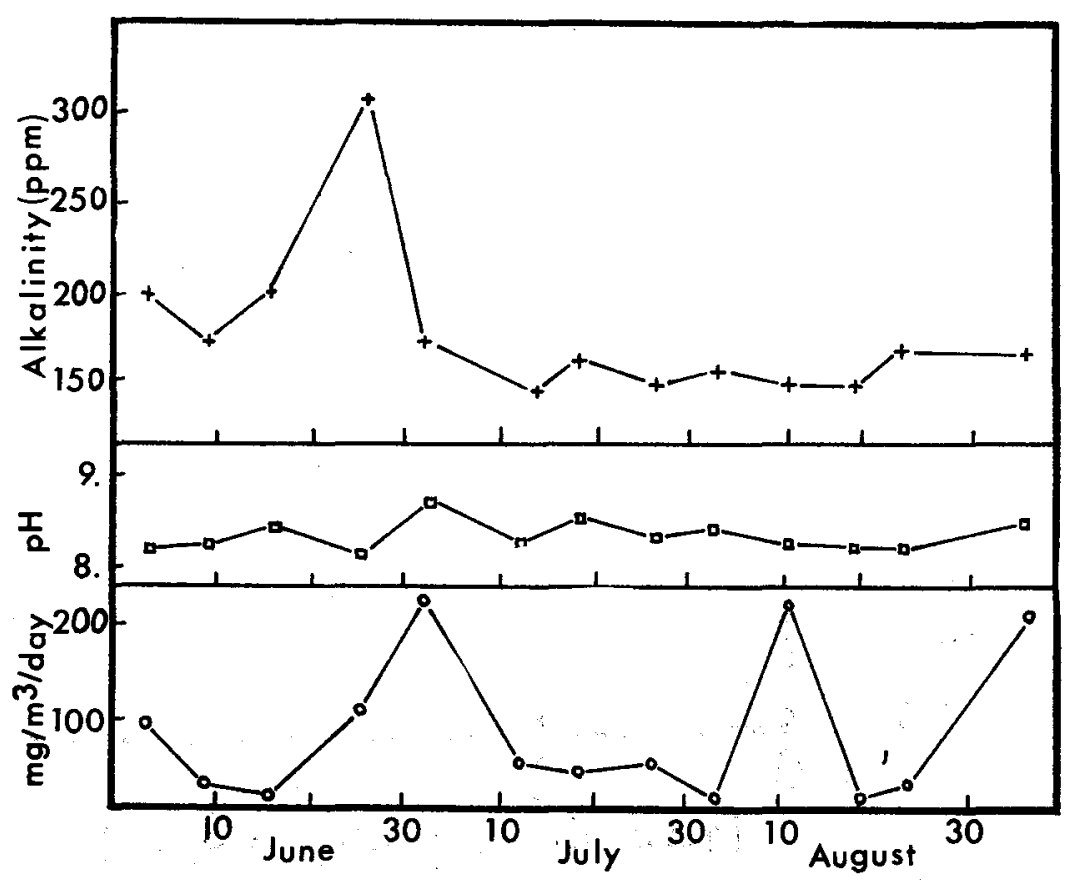

Figure 5. Day rate productivity, $\mathrm{pH}$, and alkalinity at, the $13 / 4$ meter level during the summer months, Gihbon Lake Number 4 , 1968: 
These values were again plotted (Figure 8) in order to estimate the net productivity in milligrams per square meter per year. It was estimated that 320 grams of carbon were fixed per square meter per year. It was further estimated that in the course of one year at least 1,600 $\mathrm{kg}$. of carbon are fixed by the photosynthetic process in the 1.25 acre (0.56 hectare) lake.

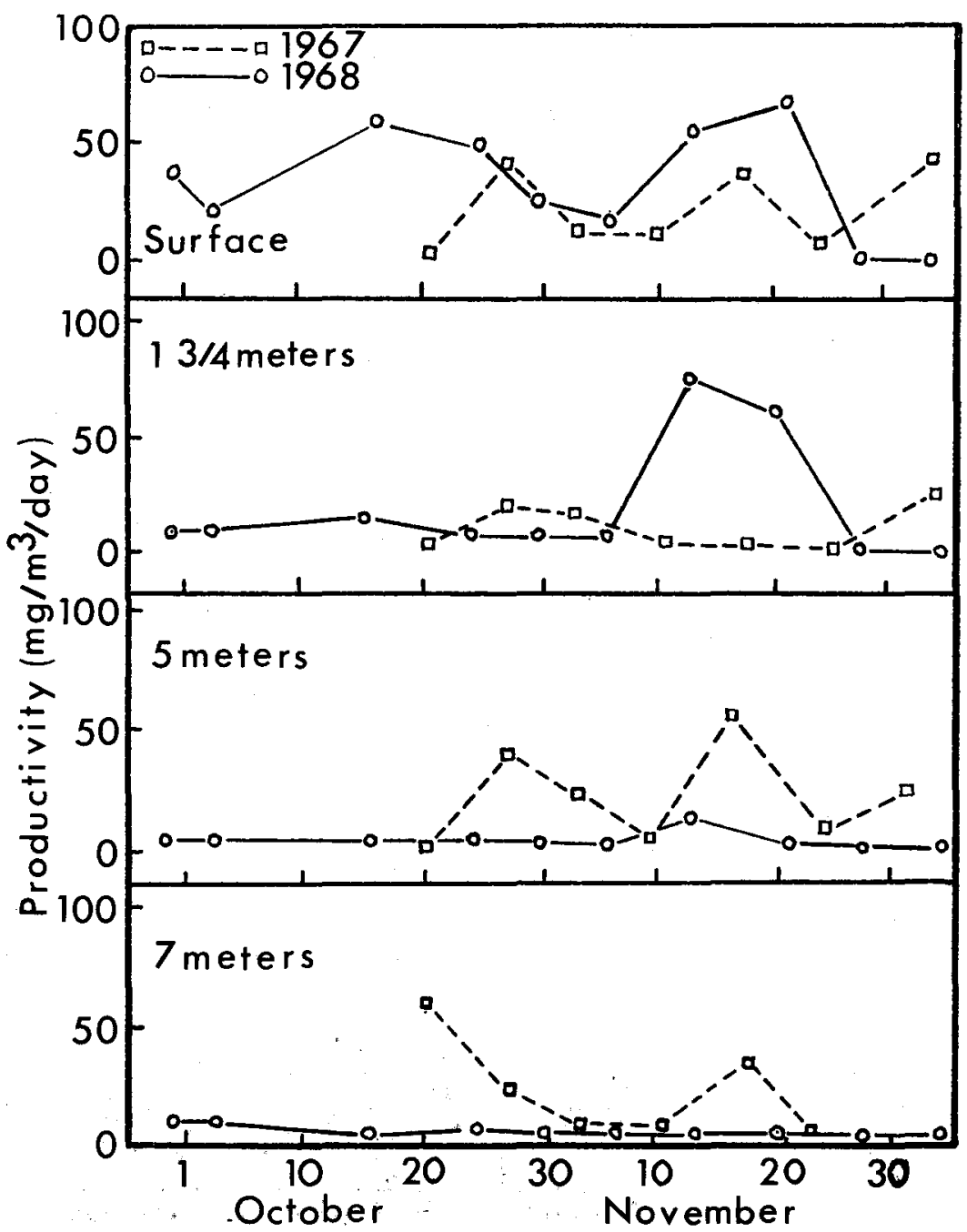

Figure 6. A compakison of estimated lay rate productivity at four depths, Glbbon Lake Number 4, 1967-68. 
The annual production of 320 grams per square meter gives an average day-rate of 870 milligrams per square meter per day. Wetzel (1963) found an annual mean productivity of 249 milligrams per square meter per day in Borax Lake, California, and Goldman (1963) found the mean productivity to be 440 milligrams per square meter per day in California. Wetzel (1966) found an annual mean of 729 milligrams per square meter per day in Goose Lake, Indiana. Various Marl type lakes studies by Wetzel (1966) show annual means ranging from about 200 to 730 milligrams per square meter per day. In a lake that he describes as partially polluted-Sylvan Lake-a mean of 1,546 milligrams per square meter per day was recorded.

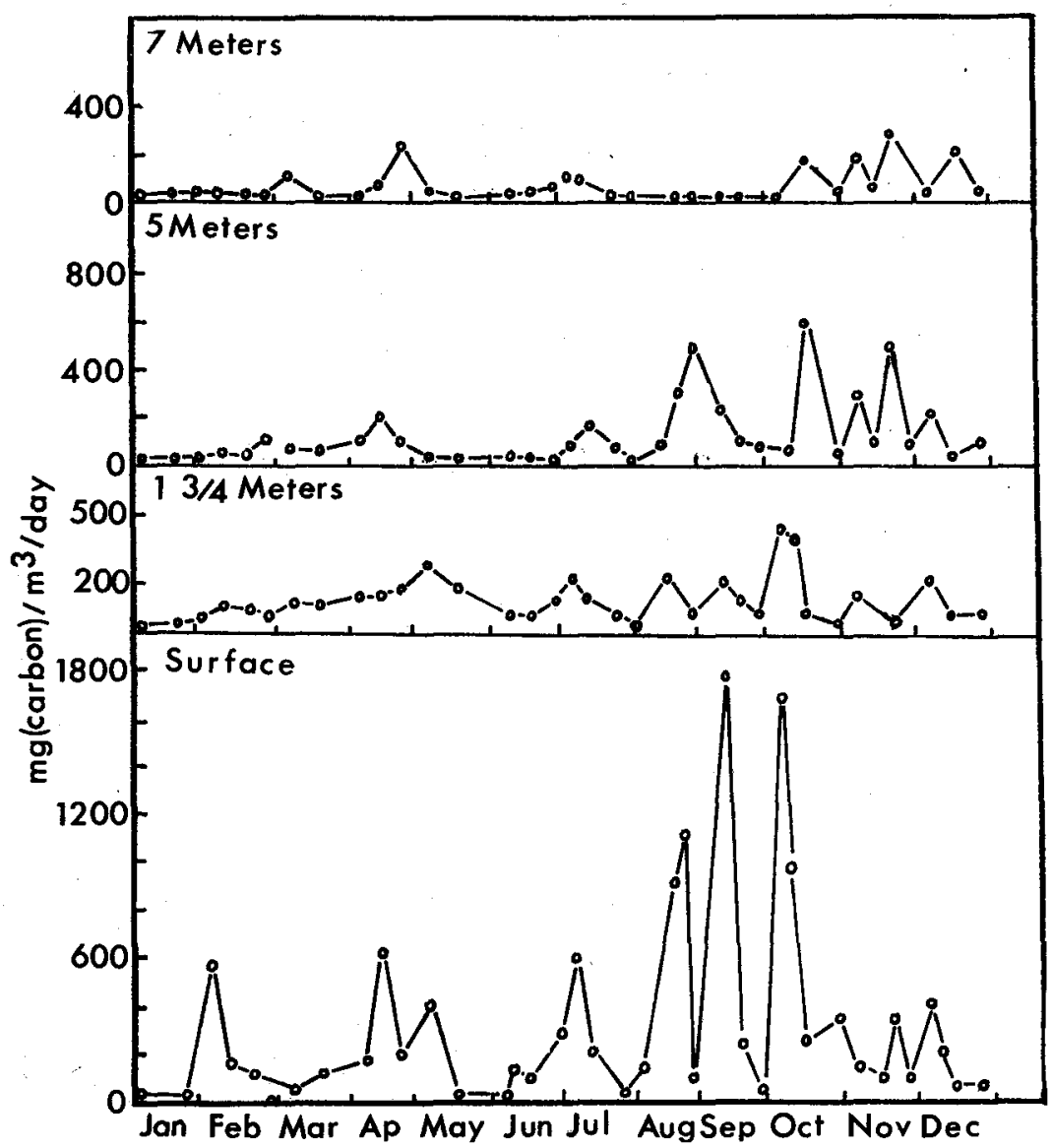

Figure 7. Estimated day rate productivity per sample date at four sampling depths, Gibbon Lake Number 4, 1968. 
None of the above lakes is similar to Gibbon Lake number 4 but the data serve to illustrate how this small eutrophic lake compares with other lakes. Except for the partially polluted Sylvan Lake, Gibbon number 4 appears to exhibit a greater mean productivity than other lakes reported.

The winter mean of 284 milligrams per square meter per day is significant when compared with annual mean of 870 milligrams per square meter per day. This shows that the winter data cannot be ignored in making estimates in annual productivity, even in lakes where the ice cover becomes significant for long periods of time.

\section{Conclusions}

The Carbon-14 method is practical for use in making estimations of primary productivity in Nebraska waters. The winter production period is significant and cannot be discounted in making yearly estimations. The productivity of this small Nebraska lake is quite high in comparison to other freshwater lakes, with peak periods of production occurring in late summer and fall.

\section{Acknowledgements}

Mr. D. B. McCarraher, Limnologist, was responsible for initiation of the study. Financial support was provided by the Nebraska Game and Parks Commission, with laboratory facilities and equipment supplied by Hastings College.

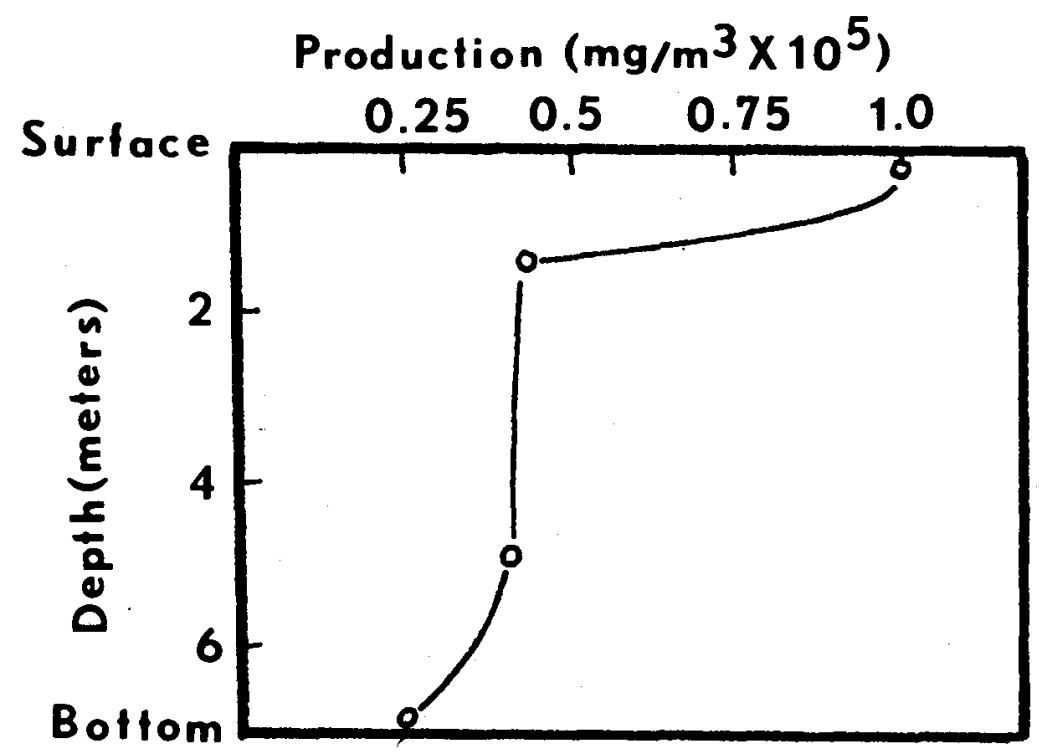

Figure 8. Net productivity for the year 1968, Gibbon Lake Number 4. 


\section{Literature Cited}

Goldman, C. R. 1963. A Study of the Primary Productivity of Clear Lake, Lake County, California. Ecology, 44(2):1963.

Saunders, G. W., F. B. Trama, and R. W. Bachman. 1962. Evaluation of a modified Carbon-14 Technique For Shipboard Estimation of Photosynthesis in Large Lakes. Publ. Great Lakes Res. Div., Univ. Mich. No. 8, $61 \mathrm{pP}$.

Stemmann-Nielson, E. 1952. The Use of Radioactive Carbon for Measurements of Organic Productivity in the Sea. Journal Conseil. 28:117-140.

Wetzel, R. G. 1964. A Comparative Study of Primary Productivity of Higher Aquatic Plants, Periphyton, and Phytoplankton in a large Shallow Lake. Internat. Rev. Ges. Hydrobiol. 49:1-61.

Wetzel, R. G. 1966. Production and Nutrient Relationship in Marl Lakes in Northern Indiana. Verh. Internat. Verein. Limnol. 16:321-332.

Wetzei, R. G. 1966. Variations in Productivity of Goose and Hypererthrphic Sylvan Lakes, Indiana. Invest. Indiana Lakes and Streams. III(5):Oct. 66.

Wetzer, R. G. 1957. Calculations in the $C^{14}$ Technique of Estimating Primary Rates of Phytoplankton. 